UDC 339.9:330.34

DOI 10.33111/iep.2019.31.02_eng

\title{
Dominants of Business Activity Globalization Processes
}

\section{KATERYNA ZHYLENKO, NATALiYA MESHKO}

\begin{abstract}
From the perspective of globalization, the newest dominants of transnationalism of business (diversification of the country structure of transnational asset with depersonification of ownership, dimensional and cluster vertical integration of transnational business entities, formation of new regional centres of accumulation of global investment asset, transition of the world economy to the sixth technological paradigm with its systemic digitization) are identified and their economic nature by a group of ruling in the global economic system dominant trends that determine the structural transformations of transnational business activity both at the level of basic and superstructure relations with its reorientation to qualitatively new technological, innovation, informational, financial, production and management platforms is explored. It is substantiated that the global stage of transnationalism of business activity has led to the formation of a qualitatively new matrix of the ratio of the two main production resources - asset and labour - which is manifested in the increasing asymmetry between the national and social nature of the expanses on the reproduction of the transnational labour power and the international private monopoly nature of appropriation of the results of its work. Global vectors of domination in corporate strategies of asset and production monopolization of mergers and acquisitions as the most effective form of concentration and centralization of MNCs` asset, as well as strengthening of their global competitive leadership in the relevant segments of the world market are revealed. The main instruments for provision of MNCs' global competitive leadership of the leading countries of the world under the conditions of formation of a multipolar world order format increase of financially reliable consumer and investment demand in the parent companies' countries, mechanisms of "soft power" and economic diplomacy towards hosting countries, widespread use of outsourcing and offshore business activity mechanisms, non-competitive status of the dollar and the euro as key reserve currencies and asset accumulation currencies, bringing to the breaking point of the system of monopolistic exploitation of global resources through artificial growth of global demand and overconsumption of material, financial and intellectual resources are specified.

The scientific hypothesis concerning the acquisition of global level of socialization of production by transnational business activity substantiated by the objective, non-convertible and ongoing process of its development, which is manifested in deepening of intra-corporate division of labour power, strengthening of interconnection and interdependence of economically, functionally and geographically separated subdivisions of MNCs, which,
\end{abstract}

* This article was translated from its original in Ukrainian.

${ }_{1}^{1}$ Zhylenko Kateryna Mykolayivna - PhD, Associate Professor, Deputy Head of the Department of Travel Business and Hospitality, Oles Honchar Dnipro National University, Associate Professor at the Department of Travel Business and Hospitality. Sphere of scientific interest: globalization of business activity, internationalization of international business, economic integration, global management of tourism business, international digitalization of business activity. E-mail: zhilenkok@ukr.net

Meshko Nataliya Petrivna - Doctor of Economics, Professor, Deputy Head of the Department of Marketing and International Management, Oles Honchar Dnipro National University, Professor at the Department of Marketing and International Management. Sphere of scientific interest: international innovative activity, global digital economy, international investment activity, global management. E-mail: nmeshko@ukr.net

IEP, № 31, (2019) pp. 43-81

(c) Kateryna Zhylenko, Nataliya Meshko, 2019 «All rights reserved»

ISSN 1811-9832/2019/№ 2 (31) 
operating under a single technological plan, adhering to the same rhythm of production and quantitative and qualitative characteristics of products, form a kind of global production organism of the creation of transnational management holdings by delegation of production and management functions to the subsidiaries of MNCs, as well as by the extension of corporate-wide boundaries of joint control and systematic financial and economic activity are specified. The forms of manifestation of global socialization are identified.

KEY WORDS: multinational corporation, business activity, transnationalism, globalization, internationalization of productive forces, global chains, multinational corporations, transnational networks, corporate strategies, integration of economic systems, world economic relations, digitization.

\section{Introduction}

Under conditions of globalization, business activity develops under the influence of various factors of deepening of the international division of labour, aggravation of competition on global markets, activation of processes of globalization and internationalization of productive forces, strengthening of consolidation of international business and activity of global companies in the new economic order. The global stage of economic systems integration is directly related to the multi-faceted internationalization process, which is the process of expanding and deepening world economic relations by increasing the mobility of factors and production results (macro-level) and attraction of firms to international operations (micro-level) ${ }^{2}$. Considering integration as the basic platform for the internationalization of economic life, it is necessary to point out the objectivity of the interaction of national economic systems and the implementation of coordinated economic policies at national and international levels in various forms (free trade, customs unions, common markets, economic unions, monetary and economic unions and political units).

In addition to the above, the leadership of multinational corporations (MNC) in implementation of the economic benefits resulting from integration processes should be recognized. The processes of regional and global integration are interconnected with the internationalization of most economic processes. Internationalization, as a process of development of the international network of economic tides and relations between national economies, in its turn, relies on transnationalism of business activity, a deepening of the processes of manufacturing and scientific and technical specialization and cooperation is taking place. In view of this, we can distinguish the most

${ }^{2}$ Global Economy in the XXI Century: Human Dimension (ukr. Globalna economica XXI stolittay: ludskyiy vymir): monograph / D.G. Lukianeneko, A.M. Poruchnyk, A.M. Kolot et al. Edited by D.Econ., Prof. D.G. Lukianeneko, A.M. Poruchnyk. K.: KNEU, 2008. - 420 p. [In Ukrainian]. 
important economic characteristics of integration under conditions of globalization for the business activities, namely:

- search for effective forms of international regulation of global economic processes;

- formation of integral regional complexes, international economic complex with general proportions and structure of reproduction;

- expanding the spatial capacity of the transnational movement of goods, labour power and assets, which is caused by the removal of administrative and economic impediments;

- international unification of the internal economic conditions of the states participating in the integration associations, equalization of the level of their economic development.

Under conditions of globalization, under the influence of external and internal factors, the main features of the macroeconomic level integration were singled out. The point at issue is the forms of trade (free trade area and customs union), productive integration (common market, economic and monetary union) and political union, which have been most clearly outlined in the EU. In their measure of development, forms of institutionalization of business activity are evolved, as enterprises get the opportunity to reorient to a qualitatively new technological, innovative, information, financial, production and management platform, which is a consequence of both the release of part of resources as a result of economic benefits realization of integration processes, and the making investments of supranational integration structures in the development of competitiveness factors.

In this context, intensive investment and innovation processes, which condition the modern development of the "knowledge civilization" and relevant international business activity, play an important role. Innovative projects cannot take place without the provision of information flows between business units and entities. In most sources, information resources in investment and innovation activities are seen by scientists and practitioners as a factor in reducing financial and economic risks. At the same time, according to O.V. Mykhailovska, the tendency to strengthen the role of information in social and economic processes suggests gives ammunition to suggest that its role in the field of investment and innovation is not limited by the reduction of the risks of investors ${ }^{3}$.

The state-of-the-art of technology development enables the active accumulation and efficient use of information as a resource, without which the activity of economic entities in the market economy

\footnotetext{
${ }^{3}$ Mychayilovska, O. V. Informational Environment Globalisation's Impact on the Development of International Innovation and Investment Processes (ukr. Vplyv globalizatsyyi informatsiyinogo prostoru na rozvytok mizhnarodnych innovatsiyino-investytsiyinych processiv): monograph. - K.: Dakor, 2009. - 424 p. [In Ukrainian].
} 
environment is impossible. Information is a determining factor in the development of economic, technical and scientific spheres of human activity, because at the moment no management decision is possible without the accumulation, processing and analysis of significant amounts of information and well-established communication processes of its interchange. In modern conditions, an important area of activity of an enterprise is its information support, which consists in gathering and processing of information necessary for making reasoned management decisions.

Modern trends in international business activity development objectively require the development of new approaches to its organization. Maintenance of the competitiveness of companies in today's world depends largely on the speed of information exchange and the speed of decision making. Electronic technologies of business operation help to increase the efficiency of these processes. In other words, the use of Internet technologies in combination with the formation of electronic markets and various virtual forms of entrepreneurship is transforming today the entire range of financial services and laying the groundwork for faster development of economic processes. Online financial services, characterized by their speed, efficiency and transparency, are able to become one of the essential accelerators of business development and growth of well-being within the scope of electronic markets. Due to this, special attention should be given to the development and improvement of this element of e-business infrastructure ${ }^{4}$.

A distinctive feature of the modern global economy is the sharp growth in particular industries of the role of MNCs from the countries with emerging markets (China, India, Brazil, Russia, South Korea, Singapore, etc.). Their active international expansion is often accompanied by conflicts of interest with the national entities of economics of the recipient countries, as well as stiff competition with the MNCs of leading countries of world economy. Despite the brisk growth of MNCs of developing countries, the top 100 of MNCs of the developing countries (less than $0.2 \%$ of total amount of MNCs in the world economy) currently control about $15 \%$ of MNCs' total external assets, which constitute over $18 \%$ of the total amount of MNCs' external sales and $14 \%$ of the MNCs ${ }^{`}$ employees $^{5}{ }^{6}$ ].

\footnotetext{
${ }^{4}$ Internet: Modern Channel and Environment for Delivering Financial Services (ukr. Merezha Internet suchasnyyi kanal I seredovische nadannya finansovych poslug) // Visnyk of the National Bank of Ukraine. 2002. - No. 6. - pp.23-29 [In Ukrainian].

${ }_{6}^{5}$ UNCTAD Official website. http://www.unctad.org

${ }^{6}$ World Development Report 2016: A Better Investment Climate for Everyone / Copublication of The World Bank and Oxford University Press, 2016. — $271 \mathrm{p}$.
} 
Taking into consideration the modification and systemic transformation of the world economy, the organizational and economic forms of multinational corporations are changing. Today, international multi-industry concerns, holding companies and diversified conglomerates are predominating. The parent companies of MNCs remain the brain centers of all production and economic and functional activities of MNCs, but the role of foreign subsidiaries is being modified. In particular, the importance of MNCs' foreign subsidiaries in creating and maintaining global competitive advantages is increasing, namely: recipient countries are actively promoting global corporate brands, outsourcing is developing, local intangible assets are being used and innovative products are being developed and distributed.

As a result of systematic transformation of the economy, with the use of such mechanisms of transnational monopolization of assets as mergers and acquisitions, territorial-sectoral clustering, cross-shareholdings, the competitive status of multinational corporations in present-day developments loses certain positions. Competition between MNCs and other international business entities is increasing, moving from the national level to the global one. As a result, the behavioral function of practically all entities of the global economy is changing, new markets are emerging, demand for international and supranational regulation and influence on multinational corporations are emerging, the level of aggressiveness of competition and its multi-polarity are increasing.

In addition, a distinguishing feature of markets, where transnational corporations dominate, is their monopolization, and in most cases, oligopolization. It should be noted that dominance in corporate strategies: monopolization of asset and production; mergers and acquisitions, are the most effective forms of concentration and centralization of MNCs assets. In its turn, this causes the strengthening of global competitive leadership of MNCs in relevant segments of the world market.

\section{Theoretical aspects of the genesis of business activity globalization}

Modern processes of economic globalization, internationalization of economic relations, especially markets, and business activities constitute a set of interrelated and interdependent processes. Transnationalism of business activity is often called a key factor in global economy formation $^{7}$. These processes form the core of the global integration

${ }^{7}$ Transnationalisation and Competitive Development of the National Economies: Theory and Practice of the Developing Countries (ukr. Transnationalizatsiya $i$ concurentnyyi rozvytok nationalnykh economik: theoriya $i$ practyka krain, scho rozvyvayutsya): monograph / L.V.Rudenko-Sudareva, O.M.Mozgovyyi, V.V. Tokar et al. : Edited by L.V.Rudenko-Sudareva. K.: KNEU, 2015. — 270 p. [In Ukrainian]. 
process, which leads to the creation of a comprehensive global economy. The imperatives that determine the formation and development of these processes are the scientific and technological development that allows the free movement of factors of production and which relies on knowledge, which are globally distributed with a considerable asymmetry; and the evolutionary valuable one that identifies a revision of the conditions of development of national economies, international economic relations, markets and the world economy on a qualitatively new, global paradigm, based on the liberalization of economic relations, law and freedom of economic agents. In addition, the contradiction between development based on objective economic laws, phenomena and processes (in particular, the deepening of the social division of labour and its highest level - the international one, and the socialization of production) and the subjective influence of individual participants of international economic relations (IER) and global economy, which reduces the predictability of IER and business activities, should be attributed to the same level of importance. At the same time, it is necessary to consider the dialectics of the global society development as a community, which is characterized by the large maladjustments and the diversity of levels, forms, mechanisms and instruments of interest and mission accomplishment.

It should be remembered that the imperative, as a category, was introduced into the science by I. Kant in the work "Critique of Pure Reason" as general rules and provisions in contradiction to personal vision, which indicates the existence of requirements of a higher nature. Objective factors, processes, and phenomena, in opposition to subjective views, reactions, and actions, are exactly what most scholars, theorists, and researchers endeavour to obtain. Therefore, knowledge of the objective laws of development of business activity transnationalism, as well as economic globalization, internationalization of economic relations are the assets that aspire to get the subjects of IER in order to obtain advantage, maximization of the effectiveness of international activities and the relations they enter into with other entities.

On the other hand, V. Robinson, as a result of the analysis of three dimensions, such as the theory of relative advantage, the theory of product cycle and the theory of transaction value, identified four global imperatives of international business development. They are the global market, global advantages, global technologies, global competition ${ }^{8}$. In his view, it is these factors that cause the formation of a global class, the core of which is two groups - transnational states and transnational

\footnotetext{
${ }^{8}$ Robinson W. I. A theory of global capitalism: Production, class, and state in a transnational world. Johns Hopkins University Press, 2004. -224 p.
} 
corporations. While identifying transnationalism as a process of international business establishment, it should be noted that its further development is determined by the global market, advantages, technologies and competition.

In the system of factors that have the greatest impact on the business activities of MNCs, the environment should be determined as the key one. According to the traditional paradigm, it is divided into internal and external, and is complemented by the concept of company-internal centralization according to $\mathrm{M}$. Taylor and $\mathrm{N}$. Trift, the organization theory of H. Simon and O. Williamson, theories of internalization and diversified diversity of business models with their industrial and regional specific features. To distinctive features of the external environment domestic scientists relegate complexity, increased risk, dynamism and uncertainty, interconnectedness of various factors, their flexibility and variability, the inability to determine the full set of factors and their features, as well as cross-competition ${ }^{9}$. They also should include the variety of forms and directions of influence of different types of environment - countries of origin, host countries, the international market and other stakeholders, which are being broadly defined by M. Porter. Also, the distinctive feature of MNCs' activities is that the activation of transnationalism leads to the tightening of common business space and the aggravation of competition between MNCs in both individual markets and globally in their pursuance of better market positions.

MNCs in their development feel the dominant influence of the business environment, the objective laws and peculiarities of development of which affect other entities in the world economic system. The study of development trends of the world economy should consider the study of objective laws and peculiarities of the transformation of the role and place of transnational corporations in them. Evidence of the relevance of this axiom is enriched by the wellknown defenders of globalization such as Hamilton L. and Werster F., who identified three key development trends of current global political economy, namely:

- increase of influence of multinational corporations;

- reduction of the influence of nation states;

- transformation of regions into new spaces of economic activity ${ }^{10}$.

Under conditions of globalization, the influence of business activities dominants has both positive and negative effects on national economies,

\footnotetext{
${ }^{9}$ Hamilton L., \& Wepster Ph. The International Business Environment. New York: Oxford University Press, 2009.

${ }^{10}$ Gilmore E., Andersson U., Memar N. How subsidiaries influence innovation in the MNE value chain // Transnational Corporations. 2018. - No. 25(1). - pp. 73-100.
} 
that is why their study aims to increase the levels of mutual satisfaction of key stakeholders, which is especially relevant in terms of ensuring sustainable development and minimization of global asymmetries. It should be treated as an objective process both the international division of labour and the socialization of production, where transnationalism serves as their form.

In this respect, it is worth agreeing with scientists who prove the possibility of using the potential of globalization to have a positive impact on the competitiveness of national economies. The point at issue is that such conditions are the congruence of interests of states and MNCs, improvement of the instruments of influence of states on the activities of MNCs, creation of mechanisms for state support to business activities of companies of the country and increase of their productivity, forming the optimal level of openness of national economies and readiness for structural changes due to globalization ${ }^{11}$. Although many aspects are often overlooked by researchers, their consideration can enhance the mutual influence of MNCs and states. We have in mind such as 1) understanding that the globalization of business activity has both direct and reverse features; 2) the formulation of national interests and security management in all their dimensions can be influenced by MNCs; 3) priority should be given to formation of a business climate with a negative attitude to corruption as opposed to seeking to influence the activities and viability of all MNCs; 4) the positive long-term impact of MNCs on the national economy may be accompanied by negative short- and medium-term negative effects on the balance of payments. To essential tasks of the state we should relegate also the priority of development of the internal market, the activation of economic and other social activities, and not the desire to use the opportunities of the global market, which should be put on the business sector, in particular the largest enterprises. The logical unity of imperatives, determinants and dominants is so complex that its visualization is a creative task, which was implemented by the key interconnections of imperatives, determinants and dominants of transnationalism of business activity (Fig. 1). In the process of studying the conceptual approaches to global aspects of business activity, it was determined that at the initial stage of MNC concept development, its traditional interpretation proceeded from the principle of unification of structures of different national affiliation (influence of the dominant

${ }^{11}$ Transnationalism and Competitive Development of the National Economies: Theory and Practice of the Developing Countries (ukr. Transnationalizatsiya $i$ concurentnyyi rozvytok nationalnykh economik: theoriya $i$ practyka krain, scho rozvyvayutsya): monograph / L.V.Rudenko-Sudareva, O.M.Mozgovyyi, V.V. Tokar et al. : Edited by L.V.Rudenko-Sudareva. K.: KNEU, 2015. — 270 p. [In Ukrainian]. 
"diversification of the country structure of multinational asset with depersonalization of property").

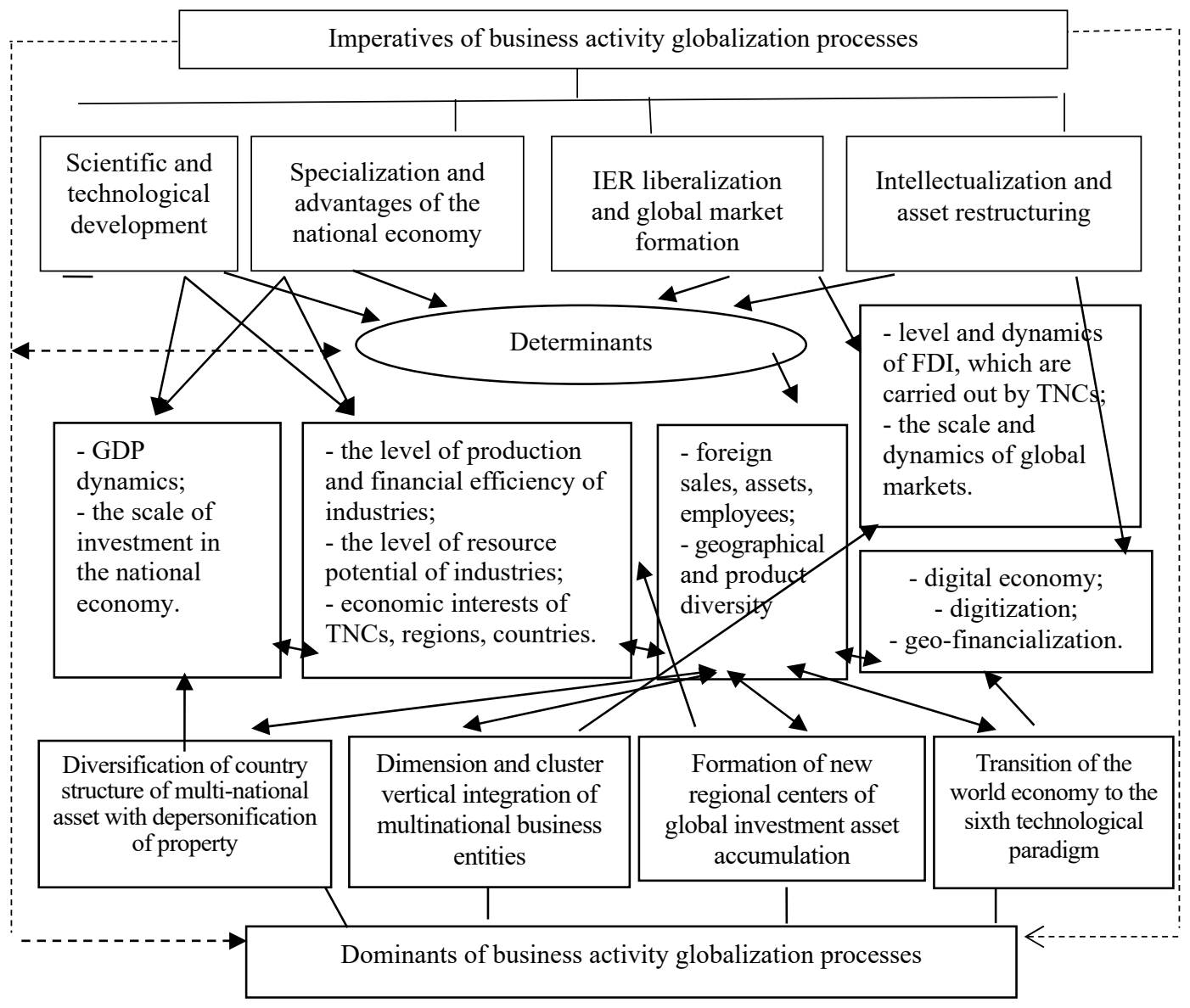

Fig. 1. Key interrelations of imperatives, determinants and dominants of business activity globalization processes

Source: developed by the authors.

The international character of the activity was implemented mainly in the selling sphere. Under the influence of the dominant "dimensional and cluster vertical integration of multinational business entities" the nature of the MNC phenomenon has changed. The leading role was played by MNCs, which included manufacturing enterprises connected by a single technological cycle, but located in different countries. 
The decisive impact on the formation, establishment, development of modern international business is carried out by innovative processes. Both major firms and separate subdivision around the world are involved in their implementation in practice ${ }^{12}$. We believe that the influence of the dominant "transition of the world economy to the sixth technological paradigm" caused the development of digitization of international communication and social networks, digital economy, international finance, increase of closeness of producers and consumers, etc.

Investments in the development of information and communication technology and computing technology have been so successful that digitization over the last 30-40 years has been called the determining factor for the development of both corporate business models and national economies. The easiness with which world-wide distances and borders can be overcome in the e-business sector makes it necessary for such companies to be aware of all levels of competitiveness provision for such companies. Digitization causes a reduction in the material intensity of FDI, which is reflected in their identification as easy ones ${ }^{13}$. Researchers argue that in this area (e-commerce, e-security, supply chain and customer relations management, e-marketing, e-services, eemployment, etc.), transnationalism can be both an opening of global opportunities and a challenge for survival. For this reason, companies should immediately develop their business activities, considering such levels of competitiveness management as internal, industrial, national and global ${ }^{14}$. This is especially relevant in the field of e-commerce, where business models can be easily replicated in different countries of the world.

We find overwhelming evidence of the interconnection of processes of internationalization of markets and transnationalism of business activity with each other and with other market development processes, industries and enterprises. Leaders of the Indian IT industry are convinced that they have been able to take advantage of the opportunities that the internationalization of the IT services market has opened up, primarily due to efficient and active innovation activity ${ }^{15}$. Such a strategy, involving numerous attempts and error, gave tangible results not only for the companies themselves, but for the entire sector of the country's economy.

\footnotetext{
12 Casella B., Formenti L. FDI in the digital economy: a shift to asset-light international footprints // Transnational Corporations. - 2018. - No. 25(1).

${ }^{13}$ Ciarniene R., Stankeviciute G. Theoretical Framework of E-Business Competitiveness // Procedia - Social and Behavioral Sciences. - 2015. - No. 213. - pp. $734-739$.

${ }^{14}$ Chatterjee C. Innovation and internationalisation in the Indian software industry // IIMB Management Review. - 2014. - No. 26. - pp.59-64.

${ }^{15}$ Odina A. N. Some consequences of markets' transnationalisation on the protection of subjective rights // Procedia Economics and Finance: Emerging Markets Queries in Finance and Business. -2015. - 32. — pp. 642 - 648.
} 
We believe that the most important factor in the business activity globalization is the technological advancements implemented by specific enterprises on the national and world markets, and which are a source of competitive advantage for the leading companies. At the same time, it should be understood that sole technological changes are not enough, and it would be more objective to consider the whole complex of factors of business activity transnationalism, which also include historical, natural, economic, political, strategic, legal, cultural components. In particular, researchers draw attention to the fact that positive law has an external effect on internal legal relations and, sometimes, leads to the absolute inefficiency of the realization of fundamental rights ${ }^{16}$. On the whole, the diversity of aspects makes multidisciplinary approaches more relevant to better understanding of phenomena and processes, problem solving and responding to the challenges of globalization.

Under conditions of globalization, business activity of enterprises is directly related to their innovative activity, which in the conditions of technoglobalism opens new opportunities but also poses new challenges. The traditional paradigm of innovation that comes from West business culture (breakthrough innovation, open innovation, social innovation, collaborative and responsible innovation), the culture of the East is trying to offer an adequate alternative. Chinese scientists in particular argue that the holistic paradigm of innovation is maturing ${ }^{17}$. It is based on four key columns of innovative technological management of firms, such as strategic importance, totality, openness and collaborationism. It is a logical consequence of the evolution of views at innovations that have dominated among Asian scientists and practitioners - imitation innovations, jugaad innovations, convergent innovations, local innovations, secondary and cross-sectional innovations. The holistic paradigm of innovation seeks not only to combine the benefits of West and East philosophy, but also to consider the international organization of practically all economic processes from the production of new knowledge to the satisfaction of consumers. Business activity in it is considered first and foremost as an instrument of a national innovationoriented strategy for the development and maintenance of global peace and sustainable development.

Depending on the technological complexity and source of origin, MNC resources may use different strategies. The complexity of the developed world markets, dominated by MNCs that have been formed over the last decades, poses a rather challenging task for emerging

\footnotetext{
${ }^{16}$ Chen J. Holistic Innovation: An Emerging Innovation Paradigm / Jin Chen, Ximing Yin, Liang Mei // International Journal of Innovation Studies. -2018. - No. 2. - pp. 1-13.

${ }^{17}$ Lynch R., Jin Z. Knowledge and innovation in emerging market multinationals: The expansion paradox // Journal of Business Research. — 2016. - No. 69. — pp. 1593-1597.
} 
markets. Depending on specific conditions, they may consider options for implementation of radical market reconfiguration strategies, organization of joint ventures, alliances or acquisition, conduction of national research and recruitment of research staff, search and acquisition of technology solutions from external sources, etc. ${ }^{18}$ In any case, companies will have to rely on a dominant innovation paradigm that will require them to acquire the relevant competencies preliminary.

The processes of globalization and the development of national policies affect each other, which happens in different forms in different countries and leads to different consequences. In different regions and countries of the world they differ - somewhere there is a strengthening, somewhere a weakening of the state; in some places, regulation is delegated to the international and supranational levels. The impact of transnationalism is typical for both developed countries, which often become the countries of MNPs ' origin, and less developed, developing countries, which are most often became host entities. The development of national economic development models is influenced by a variety of entities, including those that originate from less developed countries that can be seen from the example of economic cooperation between India and Malaysia ${ }^{19}$.

Indeed, the development of activities and the impact of various factors on the activities of MNCs should be studied and considered based on the multi-levelness of approach used. That is why a number of researchers argue that the analysis and development of MNC business activities should be considered at such five levels as individual, organizational, sectoral, national and transnational ${ }^{20}$. Accordingly, the disciplinary experience, training, provisions and values at the individual level should be considered by key contextual conditions for research of business activity transnationalism processes; at the organizational levelorganizational culture, structure and processes, resources, infrastructure and interests of stakeholders; at the sectoral level- product processes and services; at the national level - social and cultural, economic and geophysical factors, regulatory and legal frameworks and interests of national stakeholders; and at the transnational level - geopolitical factors and interests of transnational stakeholders.

The evolution of views on international business models has led to the identification of the cultural dimension as an important component

\footnotetext{
${ }^{18}$ Chandran S., Nathan K. Malaysia-India Economic Cooperation: Fixing the Jigsaw Puzzle // Procedia Social and Behavioral Sciences: GCBSS-2014, 15-16th December, Kuala Lumpur. — 2015. — 172. — pp. 359 — 366 .

19 Paul A. A multilevel approach for assessing business strategies on climate change /Paul A., Lang J., Baumgartner R.// Journal of Cleaner Production. - 2017. - 160. — pp. 50-70.

${ }^{20}$ Hofstede, G. Culture's consequences: International differences in work-related values. Beverly Hills; London: Sage Publications, 1980.
} 
of the functioning of business activity in the context of globalization. Particularly significant contributions were made by transaction cost theory, multinational firm theory, and the theory of the evolutionary process of internationalization, which made the greatest contribution based on the fundamental works of G. Hofstede, B. Kohut, and others ${ }^{21}$. Although the highest intensity of cultural interconnection (organizational, national) research is believed to have taken place between 1991 and 2000, this should not down-grade the importance of practical implementation ${ }^{22}$. In particular, the point at issue is that the issues of the development of scientific research on the principles of academic virtue have only been actively implemented in domestic practice for the last few years. Indeed, the maintenance of high ethical standards and values, the principles of sustainable development should be considered as one of the fundamental pre-requisites for successful transnationalism of business activity, entry into foreign markets, because international business is not devoid of culture. Even more, its development leads to the formation of a new culture, a culture of business that must be investigated from different perspectives.

A variety of solutions for definition of missions, forms, entities and levels of reporting relationships and control, as well as the measurement of company success, have determined the expediency of identification of all key dimensions of international business activity ${ }^{23}{ }^{24}$. As outlined above, the global paradigm of transnationalism of business activity is most clearly identified by its key dimensions (industrial and sectoral and dimensional and economic), forms (production and investment, innovative and financial and credit), as well as institutional and regulatory structures and dominant types of ownership. Generalization of the main stages of the evolution of paradigmatic foundations of transnational business activity research allowed to highlight the key dimensions of these processes. Exactly from the disclosure of the following aspects a modern understanding of the essence of transnationalism of enterprise activity is possible, namely:

- motivation of transnational activities of national companies,

- interaction with key stakeholders and the degree of their interaction,

- inter-country dislocation,

\footnotetext{
${ }^{21}$ Kogut, B., Singh, H. The effect of national culture on the choice of entry mode. Journal of International Business Studies. - 1988. - v. 19, n. 3. - p. 411-432. http://dx.doi.org/10.1057/palgrave.jibs.8490394.

${ }^{22}$ Ferreira M.P. Culture and Hofstede (1980) in international business studies: a bibliometric study in top management journals /Manuel Portugal Ferreira, Fernando Antonio Ribeiro Serra, Cláudia Safia Frias Pinto // REGE, São Paulo - SP, Brasil. - 2014. - v. 21. - n. 3. - P. 379-399. DOI: 10.5700/rege536

${ }^{23}$ Thomas Donaldson, James P. Walsh. Toward a theory of business // Research in Organizational Behavior. 2015. - 35. - P. 181-207.

${ }^{24}$ Yan L., Ming L. The Analysis on Non-Economic Influencing Factors in Transnational Mergers Made by Chinese Energy Firms Based on ESP Paradigm // Energy Procedia. — 2011. — No. 5. — pp. 69-73.
} 
- key organizational and economic forms and effectiveness of management models,

- institutional levels,

- scale of foreign production,

- scale of international employment,

- place in global value chains,

- correlation of factors of production and management,

- sectoral and industrial features and stages of development of basic goods and services,

- depth of specialization in the system of international division of labour and the degree of cooperative relations development,

- management of international competitiveness,

- possibility of factors combination.

In addition, non-economic factors, which are also considered by enterprises when making decisions also influence on the development of transnationalism processes. In particular, Chinese researches on the example of energy sector argue that political, ideological, legal, national consciousness and public opinion, trade union position, etc. should be considered as this one ${ }^{25}$. It is evident that the range of these factors can be expanded on a case-by-case basis not only by social, geographical, religious and other cultural factors, but, more importantly, it should be based on the results of preliminary study of the whole set of factors that have a decisive impact on development of specific enterprise, industry and country.

A distinctive feature of modern MNCs is the international nature of functioning not on the basis of the origin of asset, but on the geographical indication of the spread of their activities and economic interests in the context of industrial differentiation, which is due to the influence of the dominant "polycentrism of investment strategies". Of principal value is not the question of where asset comes from, but where it is forwarded and in terms of which industries. This is confirmed by the fact that the overwhelming majority of modern MNCs are formed on the basis of asset of only one national affiliation and not on the basis of multinational asset, but these MNCs operate namely on a multinational basis.

The development of any business, even in under conditions of globalization, should be seen in unity with the development of society and the local community. It should be recognized that enterprises and entrepreneurship are components of public, social, political, cultural and environmental development of communities at local and global levels,

\footnotetext{
${ }^{25}$ Wells P. Sustainable business models and the automotive industry: A commentary // IIMB Management Review. - 2013. - No. 25. - pp. 228-239.
} 
because business is primarily a social institution that cannot be considered separately or autonomously from the social architecture in which it develops. That is why simplified models of globalization and transnationalism of business activity in the direction of theories outlining, covering a wide range of factors and dimensions. In particular, the successful and unsuccessful examples of the development of international entrepreneurship in the field of automobile construction can show the importance of proper social integration of enterprises in foreign locations in the process of their transnationalism ${ }^{26}$.

Globalization processes are inextricably linked to localization, because transnationalism of business activity on the one hand implies the export of asset, and on the other, its import and placement in specific places of applied value. In particular, with the example of the wind-power industry, where up to $40 \%$ of the world's investments are from EU companies and 37\% - from China, opposite trends can be observed $^{27}$. Thus, for European companies, this is primarily about transnationalism of their business activities (creation of joint ventures for the production of turbines, technology transfer, setting up of wind farms, allowing of access to finance, acquisition of local companies). At the same time, in China, virtually all volume of investment is provided by internal investors operating in the domestic market, foreign investors' access to which is virtually restricted.

There are many facts showing the importance of research of production capacities localization, created as a result of transnationalism of business activity. In theory, the emergence of the term globalization, which is associated not only with local manifestations of global competition and the implementation of certain small localities of global scale functions, but also with the accumulation of real and financial asset. In particular, up to $80 \%$ of the global hard disk market was controlled by USA companies in separate periods of time, but only $5 \%$ was provided with production directly in the USA ${ }^{28}$. A similar example is Nestle, the vast majority of whose operations takes place outside the country of the head office. Therefore, the question of studying the international and global value chains in which national markets and manufacturers can take a variety of positions becomes more relevant. Referring to the example of wind-power development, researchers have found that European companies have to build local production chains and supply chains in order to maintain competitive positions in major

\footnotetext{
26 Lacal-Arantegui R. Globalization in the wind energy industry: contribution and economic impact of European companies // Renewable Energy. - 2019. - No. 134. - C. 612-628

${ }^{27}$ P. Gourevitch, R. Bohn, D. McKendrick, Globalization of production: insights from the hard disk drive industry // World Development. — 2000. — No. 28. — P. 301-317. https://doi.org/10.1016/S0305-750X(99)00122-9.

28 Lacal-Arantegui R. Globalization in the wind energy industry: contribution and economic impact of European companies // Renewable Energy. — 2019. — No. 134. - P. 612-628.
} 
markets (such as the USA, India, China, Brazil) ${ }^{29}$. At the same time, smaller markets become places of competition for players from large markets and, accordingly, production components tend to be more transport-logistical in their influence.

Moreover, in sectors of the economy where a great part of the added value is generated, the issues of transnationalism of business activity are different from those where savings can be made on cheaper raw materials or labour power. Therefore, the development of competitive local industrial clusters is often a factor in integrating suppliers into affiliate supply chains ${ }^{30}$. This determines not only the relevance of research of the ways of industrial clusters and value chains development, but also the implementation of national and corporate strategies for their development, which involves appropriate investment and involvement of the whole range of stakeholders.

The development of global and international value chains has a direct connection with the protection of intellectual property rights as one of the key sources of competitive advantage, and in particular with the brands used. The deployment of processes of intellectualization of economic activity, the further development of international division of labour based on the fragmentation of production, the spread of the economy knowledge and servicing have become the key factors that determine the need for intellectual property management on a national scale and in the process of transnationalism of business activity. At the same time, one should be aware of the long-term impact of intellectual asset (intellectual property item is an integral part of it) on the development of both business and national economies. Therefore, investments in their creation, protection and commercialization are longterm and in the short-term may not even have a significant impact on the business and economic development of the countries of origin ${ }^{31}$. Moreover, according to publications in leading editions, theory development and the study of development issues, fr example, such as the brand, are being studied not only in microeconomics, but also in macroeconomics, sociology, anthropology and even neuroglia.

The analysis of World Investment Reports that during many years are made by UNCTAD's permits to say that there is some cyclicality in the development of MNCs. At the same time, the overall trend over the last 25 years shows a steady increase of the transnationalism index from 50

${ }^{29}$ A. Tunisini, R. Bocconcelli, A. Pagano, Is local sourcing out of fashion in the globalization era? Evidence from Italian mechanical industry // Industrail Marketing Management. — 2011. — No. 40. - P.1012e-1023 https://doi.org/10.1016/j.indmarman.2011.06.011.

30 Ökten N. The effect of brand value on economic growth: A multinational analysis / Ökten N.Z., Okan E., Arslan U., Gungor M.// European Research on Management and Business Economics. — 2019. - No. 25. - P. 1-7.

${ }^{31}$ World investment report 2017: Investment and the Digital Economy. UNCTAD. - 252 p. https://unctad.org/en/PublicationsLibrary/wir2017_en.pdf. 
to $65 \%$ (Fig. 2). The factors embedded in the transnationalism index construction methodology are the part of foreign sales, assets and employees of the company. However, it should be indicated that not only these three aspects make it possible to talk about the development of transnationalism processes and to measure it. If we give them a generalized description, we can say that these three indicators speak of a quantitative measurement of transnationalism. That is why attempts are being made to improve transnationalism methods. In particular, domestic scientists propose to improve the index qualitatively by introducing two additional components - the sub-index of commodity (industrial) diversification and the sub-index of geographical diversification ${ }^{32}$.

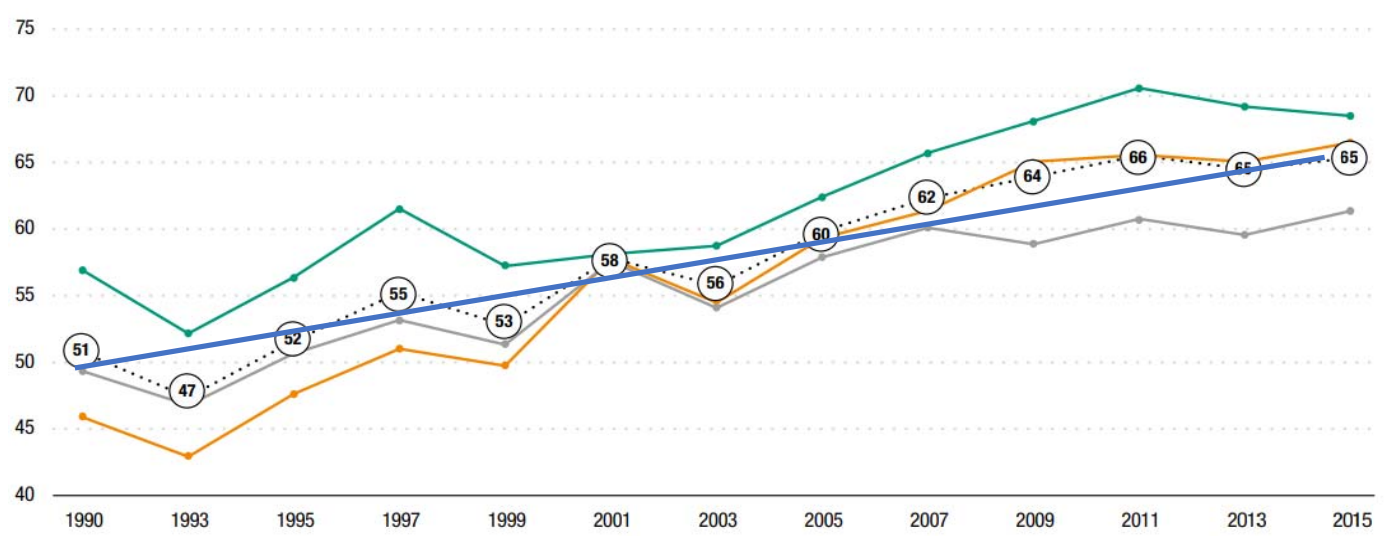

Fig. 2 Dynamics of transnationalism of the 100 largest MNCs, \%

where

- share of foreign sales

- share of foreign assets

- share of foreign employees

○ - transnationalism index

Source: developed by the author according to the data from UNCTAD ${ }^{33}$.

In addition, experts from the UNCTAD, the OECD and other international organizations regularly draw attention in their publications to the factors contributing to the development of transnationalism of business activity and mutual influence on national policies and world economic development. In particular, over the past 25 years, the field of

${ }^{32}$ World investment report 2018: investment and new industrial policies. 2018. UNCTAD. - 213 p. https://unctad.org/en/PublicationsLibrary/wir2018_en.pdf. 
increased focus of the World Investment Reports has been such trends and challenges as the transformation of origin and host countries policies, reformation of the international governance system for investment activity, formation of global value chains, non-property forms of investment activity, internationalization of markets for goods and services, competitiveness of national economies, development of economic relations, international mergers and acquisitions, employment dynamics, international integration of production, etc. ${ }^{34}$

In addition to the transnationalism index, which is key to the study of transnationalism processes, scientists propose a variety of other indicators. Depending on the awareness of the content, role, features of transnationalism of business activity, such indices of concentration of market power (Herfindahl-Hirschman Index, etc.), structural change, structure and dynamics of export and import transactions and balance of payments may apply. In addition, networking, fragmentation and segmentation of production actualize the use of indicators such as production stage quantity index, final demand distance index, participation index and global chain engagement index ${ }^{35}$.

Analysis of studies on development of MNCs and transnationalism revealed that in recent years, there has been an expansion of aspects of research of the impact of transnationalism on company performance. However, it should be acknowledged that, by and large, researchers agree that transnationalism and productivity have a direct correlation $^{36}$. Moreover, the bulk of the researches is about confirming the existence of interdependence between the fact of transnationalism and the profitability of the business or the market value of the business, confirmed by the reporting documentation. Instead, such dimensions as the depth of transnationalism (as a part of foreign business operations) and its breadth (as a geographical dispersion of multinational activity) are not sufficiently popular, which is probably explained by the difficulty of obtaining a sufficient sample of reliable data. It also explains the complexity of improved transnationalism index calculation techniques implementation.

Under condition of deployment of a knowledge-based economy, the study of the impact on MNCs performance of such factors as research and development $(R \& D)$ and others related to the generation of new and management of created knowledge and related components (human asset, infrastructure, etc.) becomes more relevant. To this day, a

\footnotetext{
34 Ibid.

35 Pires G. Multinationals, R\&D and endogenous productivity asymmetries // International Economic Journal. - 2015. - No. 29(1). - P. 95-119.

${ }^{36}$ Muratovski G. Paradigm Shift: Report on the New Role of Design in Business and Society // The Journal of Design, Economics, and Innovation. Winter 2015. — Vol. 1, No. 2. — P.118-139
} 
common practice is to consider $\mathrm{R} \& \mathrm{D}$ as an auxiliary factor contributing to enhancing the effectiveness of transnationalism ${ }^{37}$. It is clear that transnationalism has a direct, inverse and indirect effect on the performance of corporations' activity, not to say that as an entrepreneurial activity it can be negatively affected by risks and have consequences for the future of business as a whole. In particular, based on a study of 2124 MNCs from 16 key sectors of the global economy, it has been found that the depth of transnationalism has a positive impact on productivity and latitude has a negative impact; both dimensions of transnationalism have a positive effect on the activation of MNCs $\mathrm{R} \& \mathrm{D}$, which results in indirect effects on productivity, which, however, is less than the negative impact of activity geography expansion ${ }^{38}$.

Transnationalism of business activity in the face of international competitive pressure increasingly requires companies to take a total, holistic approach to consideration of virtually all aspect of activity, which is conditional upon the exhaustion of competitiveness factors productivity. In particular, with the development of the economy knowledge, the paradigm is being transformed, and one of the dimensions of the development of transnationalism processes is project development, design, which have been gaining new meaning in recent years. Design issues should no longer be considered narrowly as designing of objects, spaces, or images. However, the range of tasks of this activity is added with project development of corporate systems, strategies and experiences ${ }^{39}$. Its effective use can be transformed into a strategic resource, the basis for the development of internal and external relations, expansion of the vectors of entrepreneurship, social innovation and sustainable development, solution of problems and prevention of challenges. In some cases, you can even talk about design as a separate line of business activity.

One of the most time-tested and relevant for the deployment of transnational business activity is to recognize the project approach. On the one hand, it has been well-studied in the world scientific literature, but has only begun to develop in domestic theory and practice in recent decades. In addition to the increased risk compared to projects within the national borders, a number of other important features is pointed put - complexity, adaptability, dynamism, the need for leadership and management skills. The latter, in particular, relates primarily to the interest's area of economists and managers. Their effective use in the

\footnotetext{
37 Thamhain H. Building a Collaborative Climate for Multinational Projects // Procedia - Social and Behavioral Sciences: 26th IPMA World Congress, Crete, Greece. -2013. — No. 74 - P. 316 - 328.

${ }^{38}$ Mossolly M. Global Projects: A Conceptual Review on Execution Attitude in Multinational Corporations // Procedia - Social and Behavioral Sciences. - 2015. - No. 194. - P. $125-133$.

${ }^{39}$ Fleury, A., \& Fleury, M. T. L. Brazilian multinationals - Competences for internationalization. Cambridge, UK: Cambridge University Press, 2011.
} 
interests of successful implementation of transnationalism projects requires construction of a climate of cooperation between project team members ${ }^{40}$. Global projects are the highest form of project approach, characterized not only by the transnationalism of business activity of enterprises, but also by national economies in cooperation with enterprises (an example of which is the implementation of China's One Belt, One Road project). The last decade has witnessed the widespread implementation of global projects, the diversity of which is characterized by considerable diversification, since they can be both supracomplex and fairly simple, affecting a wide range of stakeholders and a limited range of interested beneficiaries, to be implemented on a mega-level (for example, in the oil and gas sector) and micro-level (for example, specific R\&D) or to have a multi-level nature (ICT projects) ${ }^{41}$. The factors that have led to the intensification of realization of global projects most often include the globalization of the business environment, the implementation of competitive cost management strategies, national requirements of local participation, spread of experience and knowledge, joint ventures formation, corporate mergers and acquisitions.

The variety of aspects of modern enterprise activity determines the appropriateness of proper training of both employees and the development of appropriate institutional policies and procedures. Based on a study of Brazilian MNCs, researchers have found that a competency dimension should be identified in the system of factors for successful transnationalism of business activity ${ }^{42}$. It is not only about the skills of employees, but also about the development of knowledge management systems, the formation of competent business models, protection of intellectual property rights, improvement of corporate culture, etc. International entrepreneurship, as a competence, value, form of activity and source of competitiveness, should become the core of such companies' operation. This is why successful TNCs from developing countries often resort to acquisitions of companies from more developed countries, since these aspects are more organizationally developed and more important than simple control of cheap resources. The importance of competence-based development of companies is confirmed by German researchers who, on the example of team psychoanalysis and organizational leadership in MNCs, prove the need to master coaching

\footnotetext{
40 John E.-M., West-Leuer B. Coaching in Multinational Companies an Interdisciplinary Analysis of a Management Consultant Case Narrative // Procedia - Social and Behavioral Sciences. - 2013. - No. 82.- P. $628-637$.

${ }^{41}$ Girdzijauskaite E., Radzeviciene A. International branch campus: Framework and strategy // Procedia Social and Behavioral Sciences. - 2014. - No. 110. - P. 301 - 308

42 Dimitratos P. A Missing Operationalization: Entrepreneurial Competencies in Multinational Enterprise Subsidiaries /Dimitratos P., Liouka I., Young S. // Long Range Planning. — 2014. — No. 47. — P. 64-75.
} 
tools for developing employee relations ${ }^{43}$. Transformational, situational, authentic leadership, and ethical and emotional and intelligent behaviour complement these competencies.

Transnationalism processes play a special role in the development of business activities of higher education institutions. It is obvious that industry aspects take place. In accumulated way, they can be summarized as a set of three features - full or partial ownership of a higher education institution by a foreign institution(s), carrying out of activities under the name of a foreign institution and obtainment of services and documents on behalf of a foreign institution ${ }^{44}$. It can also be observed that private higher education institutions apply to transnationalism or transnationalism is the result of targeted national strategies, for example, such as the international activities of American University in the USA, the British Council in the United Kingdom, and the National Agency for Higher Education in France. The overall impression is that transnationalism in this sector (and probably in many others) is the result of a successful combination of the interests of institutions and public financial resources.

Transfer of the competency approach from employees to other entities enables to combine and discover the competitive advantages of enterprises and countries. In particular, an analysis of literary sources on the development of MNCs revealed that the main components of entrepreneurial competence are innovation, risk-taking, proactiveness, training, networking and autonomy. At the same time, the benefits of their effective demonstration are felt by the MNCs divisions themselves and by their parent company ${ }^{45}$. The spread of the key advantages gained through the MNCs network contributes to the further improvement of competitive positions in the internal and external markets. The implementation of the competency approach is closely linked to such factors of transnationalism of business activities as concentration of resources, flexibility of investment policy, ability to participate effectively in strategic alliances, use of standardization potential.

\section{Global dominants of business transnationalism}

Modern trends in international business activity development objectively require the development of new approaches to its organization. Maintenance of the competitiveness of companies in

\footnotetext{
${ }^{43}$ Ilnytskyy D. Competitive Advantages of Transnational Corporations under the Global Economy Conditions / D. Ilnytskyy, N. Bezrukova, V. Svichkar // Economics and Region: scientific journal. PoltNTU, - 2018. — Vol. 1 (68), No. 15. - P. 118-126. https://doi.org/10.26906/eir.2018.68.1023.

${ }^{44}$ Ibid.

45 Ökten N. The effect of brand value on economic growth: A multinational analysis /Ökten N.Z., Okan E., Arslan U., Gungor M.// European Research on Management and Business Economics. - 2019. - No. 25. - P. 1-7.
} 
today's world depends largely on the speed of information exchange and the speed of decision making. Electronic technologies of business operation help to increase the efficiency of these processes. In other words, the use of Internet technologies in combination with the formation of electronic markets and various virtual forms of entrepreneurship is transforming today the entire range of financial services and laying the groundwork for faster development of economic processes. Online financial services, characterized by their speed, efficiency and transparency, are able to become one of the essential accelerators of business development and growth of well-being within the scope of electronic markets. Due to this, special attention should be given to the development and improvement of this element of e-business infrastructure ${ }^{46}$.

The transition of the world economy to the sixth technological paradigm with its systemic digitization is conditioned by the realization of the information component of the functioning of international business. At the same time, the main mechanism of implementation are digital technologies, digital economy and others, which are implemented on the platform of the international information network Internet. J. Galbraith, G. Perlmutter, S. Brown, and R. Vernoi classified the principles of the relationship between the parent company and the subsidiaries of the $\mathrm{MNCs}^{47}$. There are ethnocentric, polycentric, regiocentric and geocentric types.

It should be emphasized that ethnocentrism is more inherent to American and Japanese corporations, and polycentrism and geocentrism to West European MNCs. Generally, this hypothesis of transnationalism of business activity under the influence of the dominant can be visualized in the form of a certain system (Fig. 3).

The indicated principles are formed, in a certain way, under the influence of dominants of business activity transnationalism, such as

- diversification of country structure of transnational asset with depersonification of property,

- dimensional and cluster vertical integration of transnational business entities,

- formation of new regional centers of accumulation of global investment asset,

- transition of the world economy to the sixth technological way with its system digitization.

\footnotetext{
${ }^{46}$ World investment report 2017: Investment and the Digital Economy. UNCTAD. - 252 p. https://unctad.org/en/PublicationsLibrary/wir2017_en.pdf.

${ }_{47}$ Castellani D. Multinationality, R\&D and productivity: Evidence from the top R\&D investors worldwide /Castellani D., Montresor S., Schubert T., Vezzani A. // International Business Review. 26. — 2017. — No. 26. pp 405-416.
} 


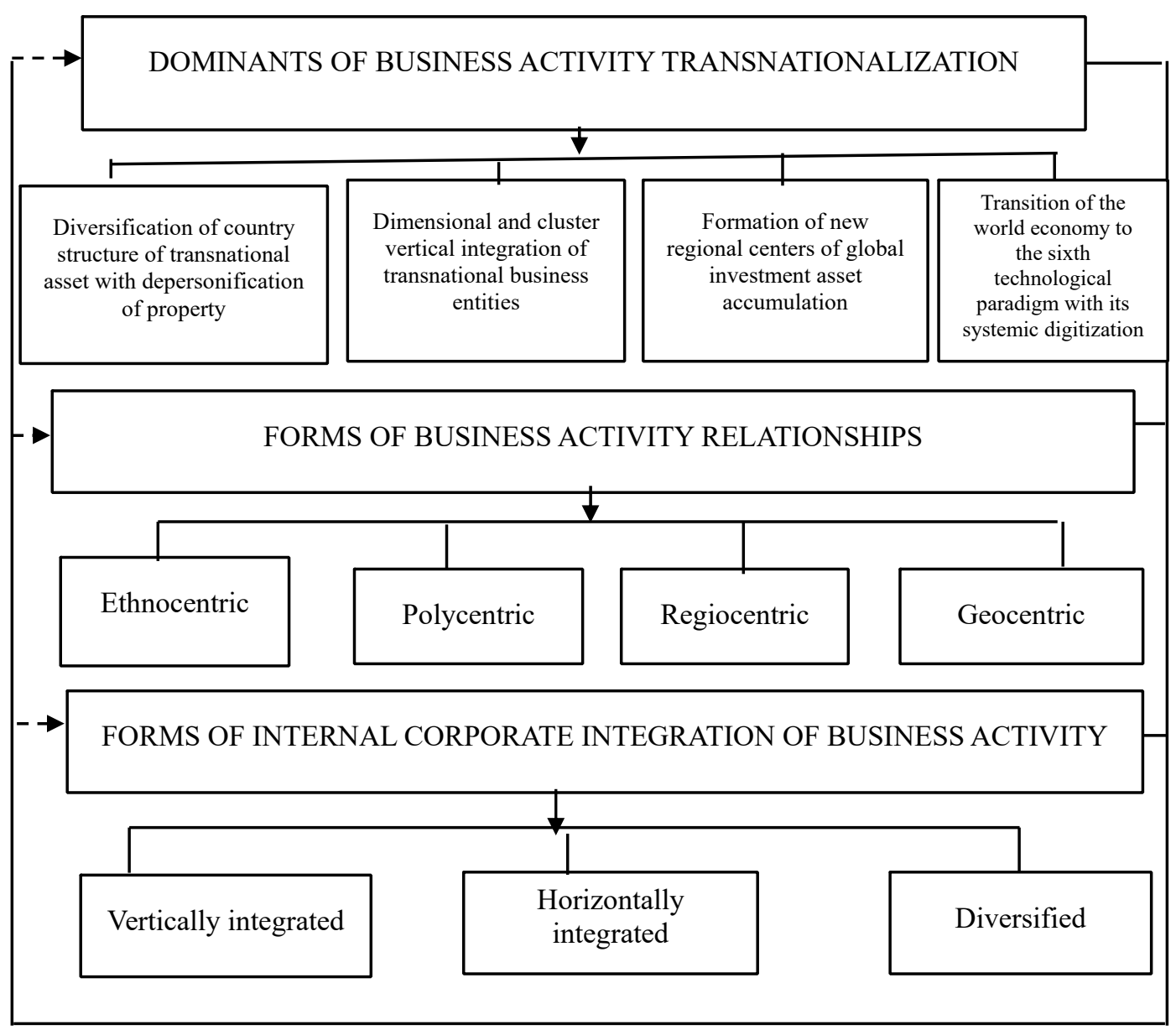

Fig. 3. System of dominants and forms of interaction of business activity under conditions of globalization

Source: developed by the authors

Globalization is characterized by the fact that transnationalism of business activity has covered virtually all countries and each of them depends on the degree of integration into the global economy. Under conditions of globalization, transnationalism of business activity acquires fundamentally new features, which are determined by the nature and specific features of the current stage of development and functioning. An important instrument of economic integration of the country into the world economy, and accordingly - an instrument of globalization, is transnationalism of business activity. Under conditions of globalization it is determined by certain features. 
At the same time, transnationalism dominants have certain characteristics and mechanisms of implementation, economic evaluation of which will allow to implement a comprehensive approach to increase the level of efficiency of transnationalism processes integration (Fig. 4).

The dominants of transnationalism of business activity, on the one hand, are the result of modern integration and globalization processes, on the other, act as the governing systems that form the modern vector of development. Impact on the process of functioning of dominants transnationalism will increase the level of business activity management both at the level of national economies and at the global level. At the same time, while distinguishing the dominants of transnationalism, it should be noted that the influence of each of them is due to the evolutionary processes of globalization of business activity.

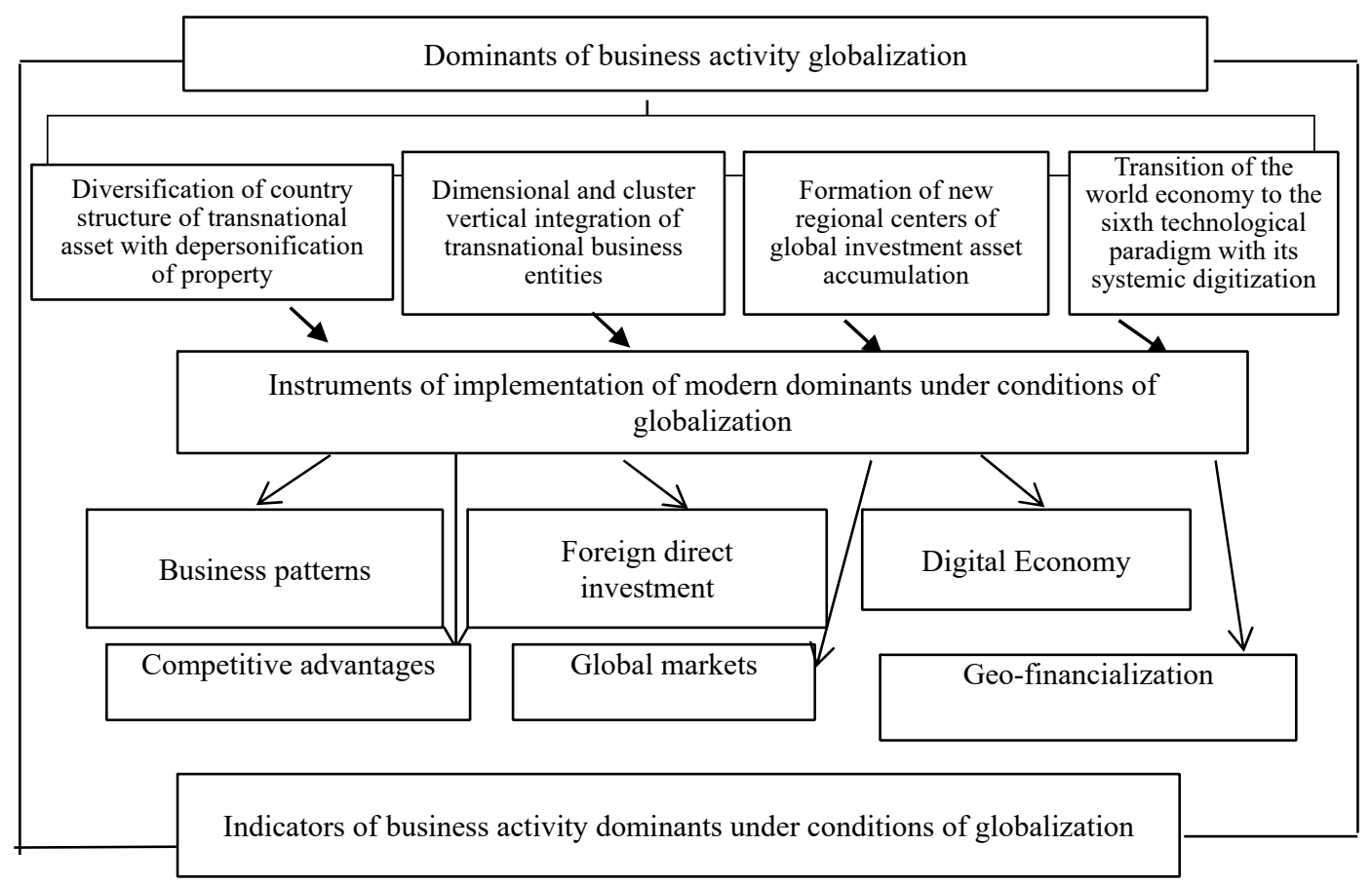

Fig. 4. Hypothesis of functioning of business activity under the influence of dominants under conditions of globalization

Source: developed by the authors

The spread of knowledge about the benefits of transnationalism and the possibilities of globalization has led to an increase in the number of MNCs, even despite the intensification of competition on the global 
market. Over the last 20 years, the number of multinationals and their subsidiaries has increased sharply. In 2015, about 82 thousand MNCs operated in the world economy. Their totality is a gigantic monopoly that operates globally, controls a significant proportion of the world production of goods, services, pricing, and appropriates monopoly-high profits. In other words, MNCs are international concerns, that is, a group of enterprises (subsidiaries) around another enterprises (parent company) that holds shares of enterprises for which control of the parent enterprise is sufficient to hold a share of $20 \%$ to $40 \%$.

Global trends in the internationalization of production and asset, privatization, strategic alliances, and foreign trade liberalization have put MNCs at the center of the global economic order. Their structure has sectoral features. Non-financial MNCs controlled the activities of approximately 860,000 foreign subdivisions, $70 \%$ of international companies belonged to the manufacturing sector, $37 \%$ to the services sector and 3\% to the construction and agriculture sectors. The dynamics of the number of multinational corporations in the world economy for 8 years shows that during the period of the global economy development under conditions of globalization, the number of MNCs in it increased by more than two times from 2010 to 2017 , and their foreign subdivisions - by more than five times. (Table 1). Therefore, trends and the further redistribution of global markets and spheres give reason to predict the likelihood of formation of global corporations by merging, acquiring or merging the largest companies in the world.

Table 1

DYNAMICS OF NUMBER OF MNCS AND THEIR SUBSIDIARIES FOR 2010-2017

\begin{tabular}{|c|c|c|}
\hline Year & $\begin{array}{c}\text { Number of parent companies, } \\
\text { units }\end{array}$ & $\begin{array}{c}\text { Number of subsidiaries (branches), } \\
\text { units }\end{array}$ \\
\hline 2010 & 35000 & 150000 \\
\hline 2011 & 39000 & 270000 \\
\hline 2012 & 52000 & 510000 \\
\hline 2013 & 63000 & 630000 \\
\hline 2014 & 64000 & 670000 \\
\hline 2015 & 77175 & 773019 \\
\hline 2016 & 79000 & 790000 \\
\hline 2017 & 82000 & 860000 \\
\hline
\end{tabular}

Source: developed by the authors according to the data ${ }^{48}$

\footnotetext{
${ }^{48}$ UNCTAD official website. http://www.unctad.org.
} 
Diversification of the country's structure of transnational asset with depersonification of ownership is a logical development of the principles of ethnocentrism and polycentrism (Fig. 5). It should be noted that the mechanism of influence of the specified dominant is implemented by investing in the raw materials of the foreign economies, which caused the genesis of the process of transnationalism by ownership (horizontally integrated international organizations).

Table 2

10 WORLD'S BIGGEST MNCS ACCORDING TO “FORTUNE” MAGAZINE, 2017

\begin{tabular}{|c|c|c|c|c|}
\hline Place & Company & $\begin{array}{c}\text { Annual income, } \\
\text { billion US } \\
\text { dollars }\end{array}$ & $\begin{array}{c}\text { Profit, billion } \\
\text { US dollars }\end{array}$ & Country \\
\hline 1 & Royal Dutch Shell & 484,489 & 30,918 & Netherlands \\
\hline 2 & Exxon Mobil & 452,926 & 41,060 & USA \\
\hline 3 & Wal-Mart Stores & 445,926 & 15,699 & USA \\
\hline 4 & BP & 386,463 & 25,700 & Great Britain \\
\hline 5 & Sinopec Group & 375,214 & 9,453 & China \\
\hline 6 & China National Petroleum & 352,338 & 16,317 & China \\
\hline 7 & State Grid & 259,142 & 5,678 & China \\
\hline 8 & Chevron & 245,621 & 26,895 & USA \\
\hline 9 & ConocoPhillips & 237,272 & 12,436 & USA \\
\hline 10 & Toyota Motor & 235,364 & 3,591 & Japan \\
\hline
\end{tabular}

Source: developed by the author according to the data ${ }^{49}$

In the world according to UNCTAD, there are about 85 thousand MNCs with 810 thousand foreign divisions. Over the past 30 years, the number of MNCs has increased by twelve times (in 1970 there were 7 thousand of such firms, in $1990-24$ thousand, in $2016-85$ thousand MNCs), employing more than 75 million people. At the same time, more than $80 \%$ of parent companies are located in the industrialized countries and about $33 \%$ of affiliates in developing countries - 19,5 and almost 50 respectfully, in the former socialist states - about 0,5 and $17 \% 5051$. The ten largest MNCs of the world according to "Fortune" magazine as of 2017 are presented in Table 2.5. The pace and structure of

\footnotetext{
${ }^{49}$ World Development Report 2016: A Better Investment Climate for Everyone / Co-publication of The World Bank and Oxford University Press, 2016. - $271 \mathrm{p}$.

${ }^{50}$ UNCTAD official website. http://www.unctad.org.

${ }^{51}$ World Development Report 2016: A Better Investment Climate for Everyone / Co-publication of The World Bank and Oxford University Press, 2016. — $271 \mathrm{p}$.
} 
transnationalism of business activity under the influence of this dominant acquire dynamic nature and transform in the context of the priority asset increase of national companies, which, as a result of increasing the level of competitiveness, consolidate their positions at the international level.

From 2000, there is an information on the announced more than 790,000 M\&A transactions of the world, for an overall amount of more than 57 trillion US dollars. Although M\&A transactions are also characterized by cyclicality, there is a general trend of their growth. In 2018, the number of transactions decreased by $8 \%$ to 49,000 transactions, and their value increased by $4 \%$ to 3.8 trillion US dollars (Fig. 5) $)^{52}$.

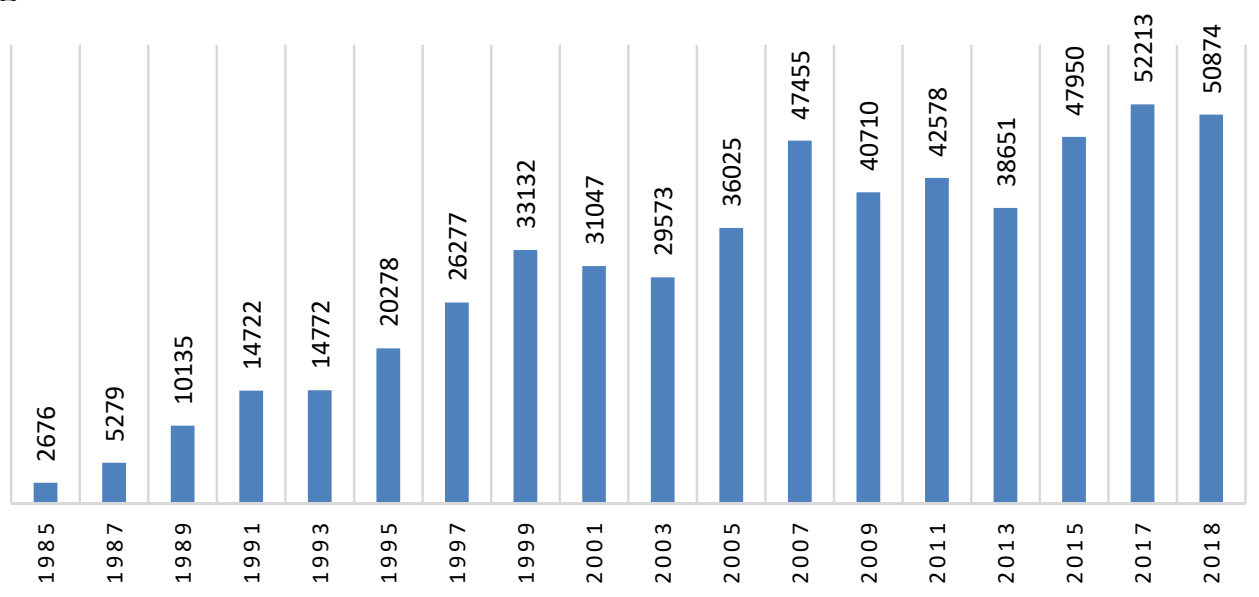

Fig. 5. Dynamics of the number of $M \& A$ transactions in the global environment, $1985-2018^{53}$

Hostile acquisition should be singled out as an important aspect of the formation of the geo-economic model of state-monopoly capitalism (Tab. 3).

Such volumes and dynamics suggest that transnational monopolization of asset and production acquire global nature. At the same time, it is necessary to realize that the primary source of such evolution is the state of development of the internal markets of the respective countries, which have formed such competitive conditions of development that national companies are quite easily resort to transnationalism, because they acquired the necessary knowledge and skills in the internal market.

\footnotetext{
52 Ibid.

${ }^{53}$ Ibid.
} 
Table 3

DISPOSITION OF COUNTRIES FOR HOSTILE ACQUISITION IN 1985-2018

\begin{tabular}{|c|l|c|c|c|c|}
\hline \multirow{2}{*}{ No. } & \multirow{2}{*}{ Target nation } & \multicolumn{2}{c|}{ Number of transactions } & \multicolumn{2}{c|}{ Cost of transactions } \\
\cline { 3 - 6 } & & items & share, $\%$ & $\begin{array}{c}\text { billion US } \\
\text { dollars }\end{array}$ & share, \% \\
\hline 1 & United States of America & 730 & 46,73 & 1209,2 & 49,28 \\
\hline 2 & Great Britain & 375 & 24,01 & 525,8 & 21,43 \\
\hline 3 & Australia & 168 & 10,76 & 62 & 2,53 \\
\hline 4 & Canada & 147 & 9,41 & 187,2 & 7,63 \\
\hline 5 & France & 38 & 2,43 & 252,6 & 10,30 \\
\hline 6 & Norway & 24 & 1,54 & 6,8 & 0,28 \\
\hline 7 & Sweden & 24 & 1,54 & 22,5 & 0,92 \\
\hline 8 & Japan & 22 & 1,41 & 11,1 & 0,45 \\
\hline 9 & Spain & 19 & 1,22 & 137,4 & 5,60 \\
\hline 10 & Ireland & 15 & 0,96 & 38,9 & 1,59 \\
\hline
\end{tabular}

Source: developed by the authors according to the data ${ }^{54}$

Sustainable development of the global economy is another aspect that is affected by the transnationalism of business activity. Aggravation of competition on the global securities market, activation of hostile acquisitions of MNCs, "freezing" of the wage fund and performance of unreasonable bonus payments to top managers of companies, deepening of intra-country and inter-regional asymmetries in the distribution of income, personalisation of global ownership and narrowing of the set of persons, who have a real control over the activities of MNCs, the intensification of the movement of fictious asset are the main components that form the "social price" of globalization.

Thus, the most developed countries in the world are responsible for the largest multinational companies, whose structure demonstrates key areas of their specialization. Asset which MNCs have (transnational asset) is involved in other countries for the development of production and distribution systems, for the implementation of a resource base (including cheaper than in the country of labour power). We conclude that the most investment-attractive among foreign investors are the industries of national economies, such as food industry and processing of agricultural products $15.7 \%$ of the total volume of foreign direct investments accumulated in international business; trade - 15.6\%; financial sphere - 8.5\%; mechanical engineering - 8.0\%; transport - 7.6\%; metallurgy and metal processing - 5.4\%; real estate operations - 4.6\%; chemical and

\footnotetext{
${ }^{54}$ Ibid.
} 
petrochemical industry $-4.1 \% 55$. At the same time, food industry, trade enterprises, financial sector, pharmaceutics are the most attractive for MNCs from EU and USA countries. In these industries, asset turnover is rapid and commercial risks are minimal. Investing in business services infrastructure for foreign investment enterprises maintenance is also attractive to MNCs from industrialized countries.

The dimensional and cluster vertical integration of transnational business entities, as the dominant of transnationalism, implements such forms of interaction between business activities as polycentrism and regional-centrism. In this context, such mechanisms of its influence as expansion and formation of a complex structure of international corporations, their sectoral and geographical spheres of activity are realized. At the same time, transnationalism of business activity is caused by an increase in the pace of activation of financial and investment activity. Thus, it is arguable that at the present stage, TNCs that have become transnational groups of companies in production, trade, financial and research profile, not only remain to be the basis of the economy of developed countries, but also one of the main catalysts for the development of developing countries (Table 4). Under conditions of globalized economy, major international companies are the main business unit, with networks of branches and subsidiaries in many countries, with employees of different backgrounds. They establish industrial, trade, scientific and technical, financial ties with their foreign partners, becoming the main source and generator of globalization.

Table 4

RATING OF THE 10 MOST PROSPECTIVE RECEIVING FDI COUNTRIES IN 2011-2017

\begin{tabular}{|l|c|c|c|}
\hline \multicolumn{1}{|c|}{ Country } & Type of economy & Place in 2011 & Place in 2017 \\
\hline China & developing & 1 & 1 \\
\hline USA & developed & 2 & 2 \\
\hline India & developing & 3 & 4 \\
\hline Indonesia & developing & 6 & 5 \\
\hline Brazil & developing & 4 & 6 \\
\hline Australia & developed & 8 & 7 \\
\hline England & developed & 13 & 9 \\
\hline Germany & developed & 8 & 10 \\
\hline Russia & developing & 5 & 9 \\
\hline Thailand & developing & 12 & \\
\hline
\end{tabular}

Source: developed by the authors according to the data ${ }^{56}$.

55 Yan L., Ming L. The Analysis on Non-Economic Influencing Factors in Transnational Mergers Made by Chinese Energy Firms Based on ESP Paradigm // Energy Procedia. - 2011. — No. 5. — P. 69-73.

${ }^{56}$ Wells P. Sustainable business models and the automotive industry: A commentary // IIMB Management Review. - 2013. - No. 25. - P. 228-239. 
Exploiting advantage of the concentration and mobilization of asset in the form of FDI determines the dominant position of MNCs at national and international levels. The scale of transnationalism of monetary and financial resources is clearly illustrated by the fact that as of April 1, 2017, the total banking assets of Ukraine corresponded to only $0.47 \%$ of the assets of the largest bank of the world "Industrial \& Commercial Bank of China Limited" 57 . The analysis of the tendencies of functioning of international business proves that one of the factors of attraction of foreign investments to the country is stimulation of the activities of TNCs, which results in diversification of the country's structure of transnational asset. Examples of global corporations represented in international business include Coca-Cola, Samsung, Toyota, Nestle, Nokia, Metro Cash \& Carry, Hewlett-Packard, British American Tobacco, Westinghouse, ExxonMobil or General Electric, Mittal Steel, etc., owners of which are distributed across a large number of countries ${ }^{58}$. Moreover, diversification and mutual ownership of shares in asset, as well as securitization of the international asset movement and increased liquidity of stock exchange securities (in particular, shares) lead to the depersonification of the ownership structure.

Dimensional and cluster integration of transnational business entities improves efficiency and effectiveness of activities and leads to the fact that multinational companies lead the world economy in different indicators. Already in 1996, their total sales amount was 5.5 trillion US dollars or $25 \%$ of world GDP, and assets of the five hundred largest non-banking MNCs exceeded 30 trillion US dollars, and $40 \%$ of assets were located outside the countries where the company's head offices are located. Currently, by various estimates MNCs is accounted for by from $1 / 4$ to $1 / 3$ of world trade. The total number of MNCs' employees exceeds 70 million. This situation is most pronounced at the financial and banking sector, where of the top three hundred largest banks in the world, more than one hundred are transnational and about $1 / 3$ of their transactions are carried out abroad. ${ }^{59}$. This is evidence of the formation of new regional centers of global investment asset accumulation, which can additionally be observed by the results of ratings of world financial centers whose activity volumes are growing annually exceeding the average GDP growth ${ }^{60}$.

${ }^{57}$ P. Gourevitch, R. Bohn, D. McKendrick, Globalization of production: insights from the hard disk drive industry // World Development. — 2000. — No. 28. — P. 301-317. https://doi.org/10.1016/S0305-750X(99)00122-9.

${ }_{58}$ Wells P. Sustainable business models and the automotive industry: A commentary // IIMB Management Review. - 2013. - No. 25. - P. 228-239.

${ }^{59}$ Thamhain H. Building a Collaborative Climate for Multinational Projects // Procedia - Social and Behavioral Sciences: 26th IPMA World Congress, Crete, Greece. -2013. — No. 74 - P. 316 - 328.

${ }^{60}$ Mossolly M. Global Projects: A Conceptual Review on Execution Attitude in Multinational Corporations // Procedia - Social and Behavioral Sciences. - 2015. - No. 194. - P. $125-133$. 
Under the influence of this dominant, the role of innovation and scientific and technological achievements is consolidated, and the organizational structure of international corporations, especially vertically integrated ones, is transformed. International holding companies (a type of multinational corporations) are formed, which conducts business activity in different national markets and aims to adapt their products and marketing strategy to local characteristics through the subsidiaries' managers. In this context, there is an intensification of the process of transnationalism of business activity, the formation of prerequisites for the functioning of a single world market and information space.

Moreover, asymmetries between the national and social nature of the costs of reproducing a transnational labour power and the international private and monopolistic nature of appropriating the results of its work are increasing. For example, the wage fund of a hired employee tends to stabilization, simultaneously charging significant bonus payments to top managers of the companies. The formation of new regional centers of accumulation of global investment asset is conditioned by the regional and centric and geo-centric forms of relationships and business activities. At the same time, with the aggravation of competition, the volume of the formation of intercompany communications systems, which acquire the status of regional (global), is transformed. Analysis of the works of domestic researchers has revealed numerous confirmations of our findings ${ }^{61}{ }^{62}$. This dominant conditions the intensification of the processes of internationalization of international business activity on the platform of integration of innovative developments, material and technical support of production, trade and distribution systems.

MNCs have now changed into transnational groups of production, trading, financial and research companies, and not only remain at the heart of the economies of developed countries, but have become one of the main forces of the world economy. First of all, this is evidenced by their dynamics: in 1976 the number of MNCs was 11 thousand (from more than 86 thousand foreign subdivisions), in the early 1990s their number exceeded 35 thousand (147 thousand foreign units). There are about 40 thousand MNCs with about 200 thousand units in 150 countries $^{63}$. MNCs have transformed the world economy into truly international production, jump-started the development of scientific and

\footnotetext{
${ }^{61}$ P. Gourevitch, R. Bohn, D. McKendrick, Globalization of production: insights from the hard disk drive industry // World Development. — 2000. - No. 28. — P. 301-317. https://doi.org/10.1016/S0305-750X(99)00122-9.

${ }^{62}$ Lacal-Arantegui R. Globalization in the wind energy industry: contribution and economic impact of European companies // Renewable Energy. - 2019. — No. 134. - P. 612-628.

63 Pires G. Multinationals, R\&D and endogenous productivity asymmetries // International Economic Journal. - 2015. - No. 29(1). - P. 95-119.
} 
technological progress in its various manifestations, provided the technical level and quality of products, increased production efficiency. It is especially important to distinguish the significance of MNCs from the point of view of improving the forms of management and organization of the enterprise, management of its commercial, production and technological and personnel potential. This is related to the importance that is given to the study of the organization and management of MNCs of integrated structures in the context of international management. Thus, the global stage of transnationalism of business activity has led to the formation of a qualitatively new matrix of the ratio of the two main production resources - asset and labour.

Investment flows coming from international companies for the modernization or development of any sphere are one of the first steps in the expansion of the national economy and the implementation of MNCs' foreign policy. The net inflow of foreign direct investment accumulated in international business totalled 534.14 billion US dollars in 2017 compared to 458.296 billion US dollars in 2016. In 2017, the global economy accumulated FDI in the amount of 753.84 billion US dollars ${ }^{64}$. On the one hand, foreign direct investments give impetus to the development of industrial sectors, on the other - the received income goes to the parent companies, depleting the resources of the host countries. Even ten largest FDI host countries have been demonstration the activation of new regional centers forming process of global investment asset accumulation (Tab. 2-3).

The formation of new regional centers of global investment asset accumulation provides transformation of the international investment environment, ensuring long-term prospects for the use of cheap sources of raw materials and fuel and energy resources, labour power for a foreign investor and enhancing its level of competitiveness. At the same time, there is a transformation of the concept of international relations in the context of aggravation of national protectionism (strengthening of economic nationalism and neo-protectionism and aggravation of contradictions between national and business interests of global asset).

In the context of globalization, the transition of the world economy to the sixth technological paradigm with its systemic digitization can be distinguished as the next dominant of transnationalism. Technological globalization, especially the possibilities of computerization, informatization and telecommunications, have already fundamentally changed the nature of international business, which in modern conditions has acquired three fundamentally new features: to be

\footnotetext{
${ }^{64}$ Muratovski G. Paradigm Shift: Report on the New Role of Design in Business and Society // The Journal of Design, Economics, and Innovation. Winter 2015. - Vol. 1, No. 2. - P.118-139
} 
efficiently carried out "from the office"; happen in the real-time mode; cover all relevant for business markets of goods, assets, labour power, information, etc., through telecommunications. Systemic digitization accurately reflects the most important feature of transnationalism of business activity in the conditions of globalization: the content of international business transactions takes the form of systemic digitization, starting from their idea and ending with a real result, becoming the core of international business, the peculiar center around which all the interests, decisions, strategies revolve around.

Analysis of the information technology market in the context of the study of the dynamics of the IT market development and the use of its products is one of the key aspects of the study of global trends of transnationalism of business activities. The main indicators used in many international research methods are the specific quantity of telecommunication devices using different technologies (Fig. 6).

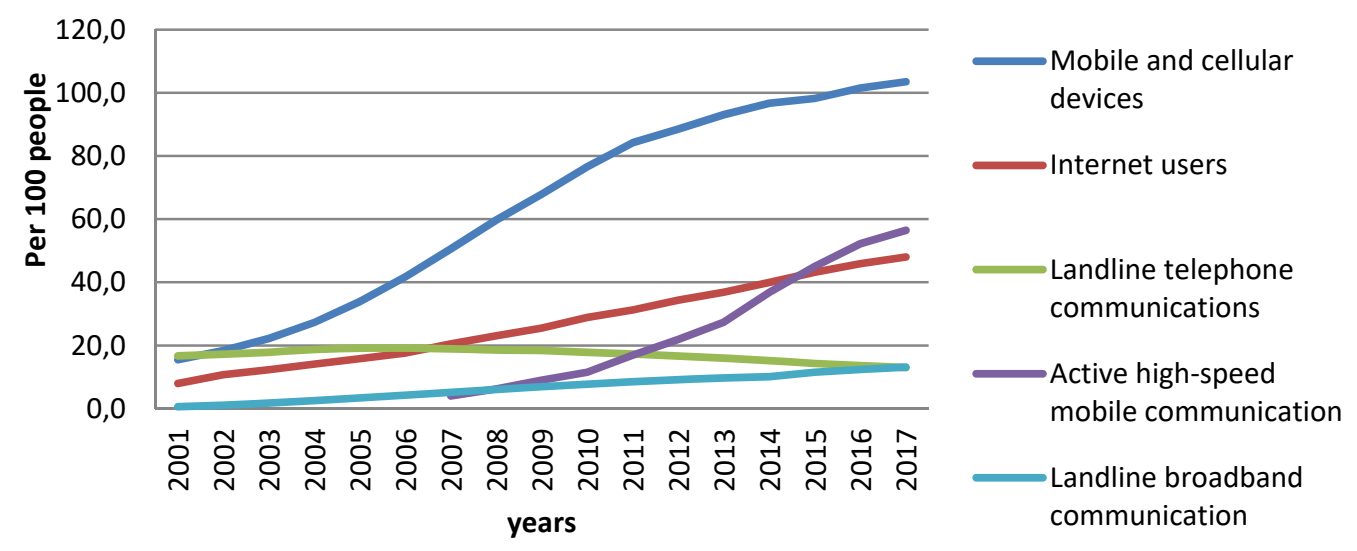

Fig. 6. Global Trends in IT Access and Use sphere per 100 people, 2001-2017

Source: developed by the author according to the data ${ }^{65}, 66$.

An analysis of the dynamics of access and use of IT indicates that there is an active increase trend for all indicators (except for landline telephone communication). This trend demonstrates the importance of the hardware segment on the global IT market from the standpoint of personal IT use. In addition, it is necessary to note the steady positive dynamics of the expansion of the information technology infrastructure

\footnotetext{
${ }^{65}$ World Development Report 2016: A Better Investment Climate for Everyone / Copublication of The World Bank and Oxford University Press, 2016. - $271 \mathrm{p}$.

66 World investment report 2017: Investment and the Digital Economy. UNCTAD. - $252 \mathrm{p}$. https://unctad.org/en/PublicationsLibrary/wir2017_en.pdf.
} 
and the growth of their use. In particular, the Internet network is transforming public relations into a global community, internationalizing them, increasing opportunities and improving the quality of access to IT products (Fig. 7).

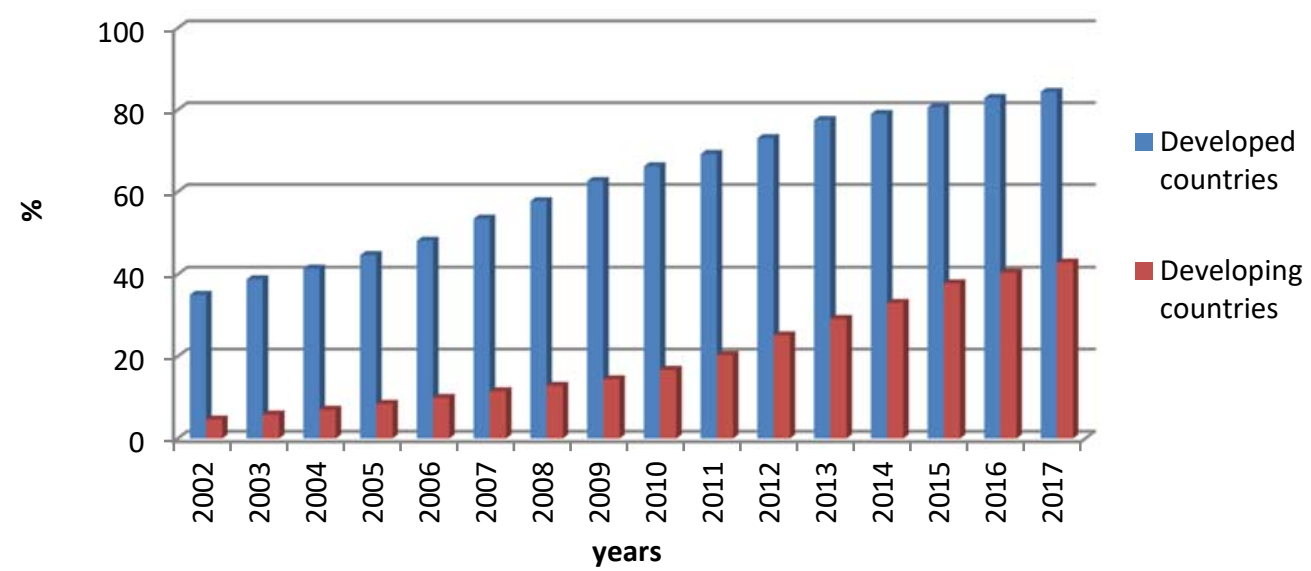

Fig. 7. Dynamics of countries' access to the global IT market in 2002-2017.

Source: developed by the author according to the data ${ }^{67}$.

Despite the fact that the availability of Internet resources has a positive growth dynamic, however, the level of Internet accessibility in developed countries is twice as much as high as this indicator in developing countries, indicating a continuing digital divide. At the same time for the period from 2015 to 2017, the intensity level of Internet resource usage increased in all the analyzed groups: for developed countries - 84.4\%, for developing countries - 42.9\%. Dynamic development of IT technologies is a key and decisive indicator of systemic digitalization of the world market, determining the global aspects of transnationalism of business activity.

Searching and usage of the international competitive advantages of IT innovation implementation has come to strictly rely on externalization of financial management systematic digitalisation, the latest and numerous financial instruments emerging from the gigantic capabilities of the global financial market. Combined with the unique capabilities of computerization and telecommunications, the priorities of emitters of numerous financial instruments are contributing to the transition of the world economy to the sixth technological paradigm with its systematic

\footnotetext{
${ }^{67}$ World investment report 2018: investment and new industrial policies. 2018. UNCTAD. - 213 p. https://unctad.org/en/PublicationsLibrary/wir2018_en.pdf.
} 
digitization, as well as the transnationalism of corporate activities, integration of national and international sectors.

Convergent and divergent processes in the field of national cultures have a complex impact on the transnationalism of business activities. On the one hand, globalization leads to exceptionally convergent processes, which leads to the formation of a multinational business culture, certain principles and rules of which are implemented by the global economy. On the other hand, national and cultural differentiation is increasing, which in extreme forms of nationalism and religious intolerance manifests itself in complex conflict forms. According to the results of the study, changes do not occur in the same way for all segments of the international market. We expect that in the future, the following segments of the global IT market will be of greatest importance: converged solutions; flash-memory for data storage systems; solutions for cloud data centers (Fig. 8).

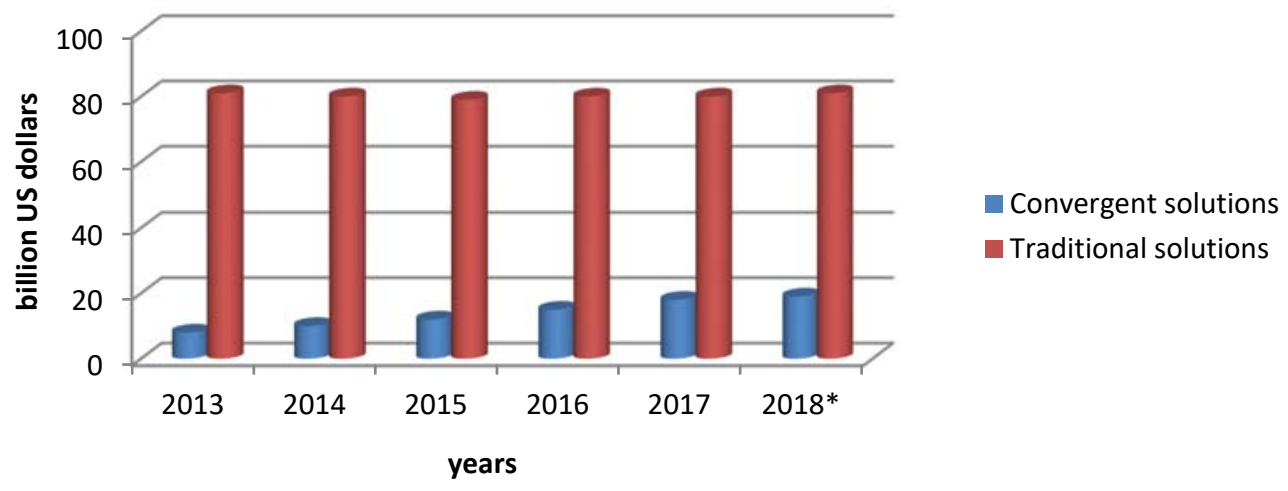

Fig. 8. Dynamics of investing in traditional and converged solutions in the context of transnationalism of business activity, 2013-2018, billion US dollars*

* projected value

Source: developed by the author according to the data ${ }^{68}, 69$.

In view of this, the dominants of transnationalism of business activity by their economic nature represent a system of prevailing trends in the world economic system, which determine the structural transformations of economies and business activities both at the level of basic and superstructural relations with its reorientation to a qualitatively new technological, innovative, informational, financial, production and

\footnotetext{
${ }^{68}$ World investment report 2017: Investment and the Digital Economy. UNCTAD. - 252 p. https://unctad.org/en/PublicationsLibrary/wir2017_en.pdf.

69 World investment report 2018: investment and new industrial policies. 2018. UNCTAD. - 213 p. https://unctad.org/en/PublicationsLibrary/wir2018_en.pdf.
} 
management platforms. In turn, the global stage of transnationalism of business activity has led to the formation of qualitatively new proportions between factors of production, which is especially shown on the example of the basic production resources - asset and labour power, the disproportion and peculiarity of reproduction of which exert pressure on the world labour and asset markets.

\section{Conclusion}

The formation of modern trends and the evolution of mechanisms that ensure the functioning of international business, in no small way are conditional upon the processes of transnationalism and globalization. The analysis of consistency and features of transnationalism of business activity allowed to identify channels, according to which the interaction between countries is made: international trade, international movement of factors of production and international financial transactions, which determine the degree of integration of national economies into the global one. The basic principles and forms of transnationalism of business activity under conditions of globalization are implemented and transformed under the influence of a certain set of managing financial and economic systems, which are the diversification of the country structure of transnational asset with erosion of ownership structure, dimensional and cluster vertical integration of the entities of transnational business, formation of new regional centers of global investment asset accumulation, transition of the world economy to the sixth technological paradigm with its digitization system.

On the one hand, the dominants of transnationalism of business activity are the result of modern integration and globalization processes, on the other, they act as managing systems that form the modern vector of development. Conscious management of the influence of transnationalism dominants will increase the quality and effectiveness level of international business management, both at the level of national economies and at the global level.

Evaluation of the degree of influence of the dominants on the process of transnationalism of business activity allowed to evaluate both the volume and depth of influence of each of the described dominants on the process of transnationalism, as well as to increase the level of efficiency of the use of financial and economic, innovation resources accumulated at the global level in the context of the functioning of national economies, whereas it objectively reflects the modern trends of international business development.

The use of fundamental analysis of the mechanisms of asset and production transnational monopolization (mergers and acquisitions, 
territorial and industrial clustering, cross-ownership of shares) has allowed to prove their global nature. The dominance in corporate strategies of priority of asset and production monopolization through mergers and acquisitions as the most effective form of concentration and centralization of MNC asset, as well as strengthening of their global competitive leadership in relevant segments of the world market, is substantiated. Dynamic transformation of the environment, especially global crises and globalization of markets, as well as high pace of development of scientific and technological progress destabilize the position of MNCs, which makes the formation of the state-monopoly capitalism model relevant.

The fast globalization in all sectors of the world economy forces MNCs to change their strategy towards the capture of the maximum possible share of the global market, the competition stifling concerning promising innovation products, regardless of their current industrial or regional specialization. The formation of a globalized business environment leads to the fact that for the development of multinational corporations the global macroeconomic development trends, especially the global economic crisis become more essential.

\section{References}

1. Casella B., Formenti L. FDI in the digital economy: a shift to asset-light international footprints // Transnational Corporations. - 2018. - No. 25(1).

2. Castellani D. Multinationality, R\&D and productivity: Evidence from the top R\&D investors worldwide / Castellani D., Montresor S., Schubert T., Vezzani A.//International Business Review. No. 26. - 2017. - pp. 405-416.

3. Chandran S., Nathan K. Malaysia-India Economic Cooperation: Fixing the Jigsaw Puzzle / / Procedia - Social and Behavioral Sciences: GCBSS-2014, 1516th December, Kuala Lumpur. - 2015. - No. 172. - pp. 359 - 366.

4. Chatterjee, C. Innovation and internationalisation in the Indian software industry / / IIMB Management Review. - 2014. - 26. - pp.59-64.

5. Chen, J. Holistic Innovation: An Emerging Innovation Paradigm / Jin Chen,Ximing Yin, Liang Mei / / International Journal of Innovation Studies. 2018. - No.2. - pp. 1-13.

6. Ciarniene R., Stankeviciute G. Theoretical Framework of E-Business Competitiveness // Procedia - Social and Behavioral Sciences. - 2015. pp. $734-739$.

7. Donaldson, T. Walsh, J.P. Toward a theory of business / / Research in Organizational Behavior. - 2015. - No. 35. - pp. 181-207.

8. Dimitratos P. A Missing Operationalization: Entrepreneurial Competencies in Multinational Enterprise Subsidiaries / Dimitratos P., Liouka I., Young S. / / Long Range Planning. - 2014. - No. 47. - pp. 64-75.

9. Ferreira M.P. et al. Culture and Hofstede (1980) in international business studies: a bibliometric study in top management journals / Manuel Portugal Ferreira, Fernando Antonio Ribeiro Serra, Cloudia Safia Frias Pinto / / REGE, 
Sго Paulo - SP, Brasil. - 2014. - Vol. 21. - No. 3. - pp. 379-399. DOI: 10.5700 / rege536.

10. Fleury, A., Fleury, M. T. L. Brazilian multinationals - Competences for internationalization. Cambridge, UK: Cambridge University Press, 2011.

11. Gilmore, E., Andersson, U., Memar N. How subsidiaries influence innovation in the MNE value chain // Transnational Corporations. 2018. No. 25(1). - pp. 73-100.

12. Girdzijauskaite E., Radzeviciene A. International branch campus: Framework and strategy // Procedia - Social and Behavioral Sciences. 2014. - No. 110. - pp. $301-308$.

13. Global Economy in the XXI Century: Human Dimension (ukr. Globalna economica XXI stolittya: ludskyiy vymir): monograph / D.G. Lukianeneko, A.M. Poruchnyk, A.M. Kolot et al. Edited by D.Econ., Prof. D.G. Lukianeneko, A.M. Poruchnyk. K.: KNEU, 2008. - 420 p. [In Ukrainian].

14. Gourevitch, P., Bohn, R., McKendrick, D. Globalization of production: insights from the hard disk drive industry / World Development. - 2000. No. 28. - pp. 301-317. https://doi.org/10.1016/S0305-750X(99)00122-9.

15. Hamilton, L., Wepster, Ph. The International Business Environment. New York: Oxford University Press, 2009.

16. Hofstede, G. Culture's consequences: International differences in workrelated values. Beverly Hills; London: Sage Publications, 1980.

17. Ilnytskyy D. Competitive Advantages of Transnational Corporations under the Global Economy Conditions / D. Ilnytskyy, N. Bezrukova, V. Svichkar / / Economics and Region: scientific journal. PoltNTU, - 2018. - Vol. 1 (68), No. 15. - pp. 118-126. https://doi.org/10.26906/eir.2018.68.1023.

18. Internet: Modern Channel and Environment for Delivering Financial Services (ukr. Merezha Internet - suchasnyyi kanal I seredovische nadannya finansovych poslug) / Visnyk of the National Bank of Ukraine. - 2002. No. 6. - pp.23-29 [In Ukrainian].

19. John E.-M., West-Leuer B. Coaching in Multinational Companies an Interdisciplinary Analysis of a Management Consultant Case Narrative / / Procedia - Social and Behavioral Sciences. - 2013. - No. 82.- pp. 628 - 637.

20. Kogut, B., Singh, H. The effect of national culture on the choice of entry mode. Journal of International Business Studies. - 1988. - Vol. 19, No. 3. pp. 411-432. http: / /dx.doi.org/10.1057/palgrave.jibs.8490394.

21. Lacal-Arantegui R. Globalization in the wind energy industry: contribution and economic impact of European companies // Renewable Energy. - 2019. No. 134. - pp. 612-628.

22. Lynch R., Jin Z. Knowledge and innovation in emerging market multinationals: The expansion paradox // Journal of Business Research. 2016. - No. 69. - pp. 1593-1597.

23. Muratovski G. Paradigm Shift: Report on the New Role of Design in Business and Society // The Journal of Design, Economics, and Innovation. Winter 2015. - Vol. 1, No. 2. - pp.118-139.

24. Mychayilovska, O. V. Informational Environment Globalisation's Impact on the Development of International Innovation and Investment Processes (ukr. Vplyv globalizatsyyi informatsiyinogo prostoru na rozvytok mizhnarodnych innovatsiyino-investytsiyinych processiv): monograph. - K.: Dakor, 2009. 424 p. [In Ukrainian]. 
25. Mossolly M. Global Projects: A Conceptual Review on Execution Attitude in Multinational Corporations / / Procedia - Social and Behavioral Sciences. 2015. - No. 194. - pp. 125 - 133.

26. Nenno, I.M. Dimensions of Transnationalism (ukr. Vymiry transnationalizatsiyi) / I. M. Nenno / / Rynkova economika: suchasna theoriya $i$ practyka upravlinnya. - 2014. - Vol. 1, No. 2. - pp. 58-69. http://nbuv.gov.ua/UJRN/rectpu_2014_1_2_9 [In Ukrainian].

27. Odina, A. N. Some consequences of markets' transnationalism on the protection of subjective rights //Procedia Economics and Finance: Emerging Markets Queries in Finance and Business. -2015. - No. 32. pp. 642 - 648.

28. Lkten N. The effect of brand value on economic growth: A multinational analysis / Цkten N.Z., Okan E., Arslan U., Gungor M. / European Research on Management and Business Economics. - 2019. - No. 25. - pp. 1-7.

29. Paul A. A multilevel approach for assessing business strategies on climate change / Paul A., Lang J., Baumgartner R. / / Journal of Cleaner Production. 2017. - No. 160. - pp. 50-70.

30. Pires G. Multinationals, R\&D and endogenous productivity asymmetries International Economic Journal. - 2015. - No. 29(1). - pp. 95-119.

31. Robinson, W. I. A theory of global capitalism: Production, class, and state in a transnational world. Johns Hopkins University Press, 2004. - 224 p..

32. Tunisini, A., Bocconcelli, R., Pagano, A. Is local sourcing out of fashion in the globalization era? Evidence from Italian mechanical industry / / Industrial Marketing Management. - 2011. - No. 40. - pp.1012-1023. https: / /doi.org/10.1016/j.indmarman.2011.06.011.

33. UNCTAD Official website. http://www.unctad.org.

34. World Development Report 2016: A Better Investment Climate for Everyone / A Copublication of The World Bank and Oxford University Press, 2016. - 271 p.

35. Thamhain H. Building a Collaborative Climate for Multinational Projects / / Procedia - Social and Behavioral Sciences: 26th IPMA World Congress, Crete, Greece. - 2013. - No. 74 - pp. 316 - 328.

36. Transnationalism and Competitive Development of the National Economies: Theory and Practice of the Developing Countries (ukr. Transnationalizatsiya $i$ concurentnyyi rozoytok nationalnykh economik: theoriya $i$ practyka krain, scho rozvyvayutsya): monograph / L.V.Rudenko-Sudareva, O.M.Mozgovyyi, V.V. Tokar et al. : Edited by L.V.Rudenko-Sudareva. K.: KNEU, 2015. - 270 p. [In Ukrainian].

37. Wells P. Sustainable business models and the automotive industry: A commentary / / IIMB Management Review. - 2013. - No. 25. - pp. 228-239.

38. World investment report 2017: Investment and the Digital Economy. UNCTAD. - 252 p. https: / / unctad.org / en / PublicationsLibrary / wir2017_en.pdf.

39. World investment report 2018: investment and new industrial policies. 2018. UNCTAD. - 213 p. https://unctad.org/en/PublicationsLibrary / wir2018 en.pdf.

40. Yan L., Ming L. The Analysis on Non-Economic Influencing Factors in Transnational Mergers Made by Chinese Energy Firms Based on ESP Paradigm / / Energy Procedia. - 2011. - No. 5. - pp. 69-73.

The article was received by the Editorial Board on August 15, 2019. 